\title{
The Digestion of Protein and Carbohydrate by the Stream Detritivore, Tipula abdominalis (Diptera, Tipulidae)
}

\author{
M.M. Martin ${ }^{1}$, J.S. Martin ${ }^{1}$ and J.J. Kukor ${ }^{1}$, and R.W. Merritt ${ }^{2}$ \\ ${ }^{1}$ Division of Biological Sciences, University of Michigan, Ann Arbor, Michigan, 48109, \\ ${ }^{2}$ Department of Entomology, Michigan State University, East Lansing, Michigan, 48825, USA
}

Summary. The digestive system of larvae of Tipula abdominalis (Diptera, Tipulidae), a stream detritivore, is poorly adapted for the digestion of the major polysaccharides in its diet, but well adapted for the digestion of protein. These crane fly larvae are unable to digest the major cell wall polysaccharides of higher plants, i.e., cellulose, hemicellulose and pectin. The only polysaccharides toward which the midguts of $T$. abdominalis exhibited any activity were $\alpha$-amylose and laminarin, indicating that polysaccharide digestion is restricted to $\alpha-1,4$ and $\beta-1,3$-glucans. The most concentrated source of these two classes of carbohydrates in submerged leaf litter would be associated fungal tissue. The midgut of $T$. abdominalis is strongly alkaline throughout, with a maximum $\mathrm{pH}$ near 11.5 in a narrow zone near the midpoint. Proteolytic activity in the midgut is extraordinarily high, and the $\mathrm{pH}$ optimum for midgut proteolytic activity is above 11 . We conclude that the high alkalinity and high proteolytic activity observed in $T$. abdominalis. larvae are manifestations of a highly efficient protein-digesting system, a system of crucial importance to a nitrogen-limited organism which must derive its nitrogen from a resource in which much of the limited nitrogen present is in a "bound" form in complexes of proteins with lignins and polyphenols.

\section{Introduction}

Detritus is generally considered to be a resource of limited nutritive value (Willoughby 1974; Berrie 1976; Anderson and Sedell 1979; Cummins and Klug 1980). Not only are nitrogen levels low, but much of the protein which is present is complexed with tannins and lignins, presumably making it difficult to digest (Suberkropp et al. 1976; Odum et al. 1979). Furthermore, most of the carbon of litter is present in highly refractive structural polymers, such as cellulose, hemicellulose and lignin. The low nutritive quality of detritus is reflected in the low values of approximate digestibility (AD) and efficiency of conversion of ingested food (ECI) recorded for detritus-feeders (Waldbauer 1968; Cummins et al. 1973; Iversen 1974; Cummins and Klug 1980). The most nutritious component of litter is the associated microbial biomass, and many studies have demonstrated a clear preference on the part of detritivores for litter which supports a rich culture of microorganisms, especially fungi (Kaushik and Hynes 1971; Mackay and Kalff 1973; Bärlocher and Kendrick 1976; Berrie 1976; Suberkropp and Klug 1976; Anderson and Sedell 1979; Cummins and Klug 1980).

Offprint requests to M.M. Martin
In spite of the low nutritive value of detritus, food webs based upon its use dominate many aquatic ecosystems. The larvae of caddisflies (Trichoptera), crane flies (Diptera) and stoneflies (Plecoptera) are the major consumers of course particulate organic matter (CPOM) in woodland streams (Berrie 1976; Cummins 1978; Andersen and Sedell 1979; Cummins and Klug 1980). The digestive mechanisms employed by detritus-feeders in meeting their nutritional requirements while feeding upon a resource with low apparent nutritive value has received little study. Bjarnov (1972) established that the aquatic larvae of several species of caddisflies possess limited capacity to digest the major structural polysaccharides of plant tissue, i.e. cellulose, hemicellulose and pectin, but commonly contain within their digestive fluids enzymes active against classes of polysaccharides widely distributed in fungi. Nielsen $(1962,1963)$ reported similar findings in a number of terrestrial detritivores, including two species of crane flies. Thus, with respect to their capacity to digest naturally occurring polysaccharides, many detritivores resemble fungivores (Martin et al. 1980) more than herbivores. However interesting these studies on carbohydrate digestion might be, an understanding of protein digestion is more likely to provide crucial insights into detritivore biology, since these organisms are nitrogen-limited (Iversen 1974).

The present investigation is an examination of the digestive biochemistry of the larvae of the crane fly, Tipula abdominalis (Say) (Diptera, Tipulidae), an abundant shredder of leaf litter in Michigan streams. We have explored both carbohydrate and protein digestion, and have identified several characteristics which appear to be crucial to the ability of this species to exploit the limited nutritive potential of its food.

\section{Materials and Methods}

Animals

T. abdominalis larvae were collected in January and in early April from naturally occurring leaf packs in Smith Creek (Barry County, Michigan) and in May from a tributary of Fleming Creek (Washtenaw County, Michigan). Larvae were maintained in the laboratory in shallow pans in aerated natural stream water at $5^{\circ} \mathrm{C}$. Distilled water was added occasionally to compensate for evaporation. They were fed leaf litter collected from the streams of origin.

\section{Preparation of Extracts}

Live larvae were dissected under distilled water by holding the epidermis firmly in two pairs of forceps at a lateral position near the posterior end and tearing an opening, which was extended both circumferentially and anteriorly until the entire gut was exposed. The gut was carefully 
freed of connections to adjacent tissues and then severed in the ileum slightly posterior to the juncture with the Malpighian tubules (Fig. 1). The individual gut segments were freed by pinching with forceps, and placed in small homogenizing tubes in an ice bath.

Gut segments with contents intact, from 3-10 individuals, were homogenized by hand in about $1 \mathrm{ml}$ of distilled water. Following centrifugation $\left(10,000 \times \mathrm{g}, 20 \mathrm{~min}, 5^{\circ} \mathrm{C}\right)$, the pellet was resuspended in about $1 \mathrm{ml}$ of water, centrifuged as before, and the supernatant combined with the original extract. The extract was made up to a volume which was an integral multiple of $2.5 \mathrm{ml}$, and $2.5 \mathrm{ml}$ aliquots were placed on Sephadex G-25 M columns $(1.7 \times 5.0 \mathrm{~cm}$, Pharmacia Fine Chemicals, PD-10 Columns). Proteins were eluted in $3.5 \mathrm{ml}$ of water.

\section{Measurement of Gut pH Gradient}

Measurement of $\mathrm{pH}$ were made on the intact gut, exposed along most of its length while still in the larva, by folding back adjacent tissues and inserting a combination $\mathrm{pH}$ microelectrode (BioRad 163-2013) at intervals of about $3 \mathrm{~mm}$. No significant mixing of the contents was evident during these manipulations.

\section{Enzyme Assays}

Proteolytic activity was assayed using Azocoll (Calbiochem 19493) as substrate. A $0.5-\mathrm{ml}$ aliquot of the test solution, plus $0.5 \mathrm{ml}$ of buffer, was incubated with $25 \mathrm{mg}$ of Azocoll at the test temperature for an appropriate time period ( $3 \mathrm{~min}$ to $4 \mathrm{~h}$, depending upon the temperature and concentration). The incubation was terminated by the addition of $3.0 \mathrm{ml}$ of $10^{-2} \mathrm{M} \mathrm{HCl}$ and rapid filtration through $1-2 \mathrm{~mm}$ of Celite supported on a small, coarse sintered funnel. Absorbance of the filtrate at $520 \mathrm{~nm}$ was measured.

Activities toward microcrystalline cellulose (Polyscience 4853), potato amylose (Calbiochem 172681), carboxymethylcellulose (Sigma C8758), laminarin (Calbiochem 428001), larchwood xylan (Sigma X-3875), locust bean gum (Sigma G-0753) and citrus pectin (Sigma P-9135) were assayed by measuring the rate of liberation of reducing groups (maltose equivalents), using the 3,5-dinitrosalicylic acid reagent (Bernfeld 1955), as adapted by Martin et al. (1980). Activity toward $\gamma$-chitin (Calbiochem 220463) was assayed by measuring the rate of liberation of $\mathrm{N}$-acetylglucosamine (Reissig et al. 1955; Waterhouse et al. 1961).

Controls in all of the above enzyme assays were run using aliquots of extract inactivated by heating.

The buffers used routinely in these assays were $0.1 \mathrm{M}$ potassium phosphate ( $\mathrm{pH} 7.5), 0.1 \mathrm{M}$ sodium carbonate $(\mathrm{pH} 9.5), 0.1 \mathrm{M}$ sodium glycinate $(\mathrm{pH} 9.5)$, and $0.1 \mathrm{M}$ potassium phosphate ( $\mathrm{pH} 11.5$ ). $\mathrm{pH}$ profiles of enzyme activity were established using the following buffers: $0.1 \mathrm{M}$ acetate $(\mathrm{pH} 5.1,5.6), 0.1 \mathrm{M}$ phosphate $(\mathrm{pH} 6.0,6.5,7.0,7.5)$, $0.1 \mathrm{M}$ Tris ( $\mathrm{pH} 8.0,8.5,9.0), 0.1 \mathrm{M}$ carbonate ( $\mathrm{pH} 9.5,10.0,10.5,11.0$ ), and $0.1 \mathrm{M}$ phosphate ( $\mathrm{pH} 11.5,12.0,12.5)$.

\section{Results and Discussion}

The midgut of T. abdominalis is alkaline throughout, with a maximum $\mathrm{pH}$ of 11.0 to 11.6 occurring near the midpoint (Fig. 1). The $\mathrm{pH}$ of 11.6 recorded in the midguts of two individual larvae is, we believe, the highest $\mathrm{pH}$ recorded in any insect's gut. The rectal caecum and rectum are only slightly alkaline, having $\mathrm{pH}$ 's between 7.1 and 7.5. Two other groups of aquatic detritivores, mosquito larvae (Dadd 1975) and blackfly larvae (Lacey and Federici 1979; Undeen 1979), have also been reported to have highly alkaline midguts.

It is reasonable to presume that the alkalinity of the midguts of these detritus-feeding larvae is an adaptation to the bound state of the protein present in their detrital food. Many herbivorous lepidopteran larvae also possess alkaline midguts, and it has

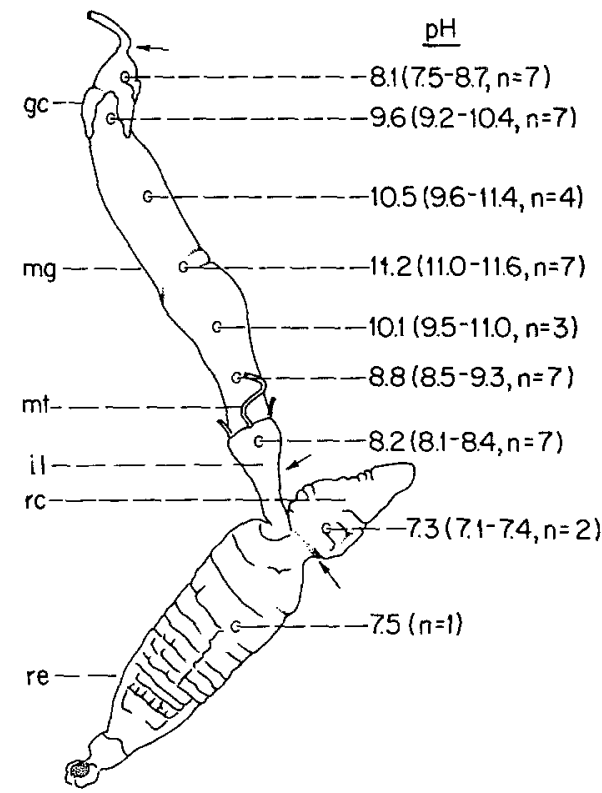

Fig. 1. Digestive tract of $T$. abdominalis showing $\mathrm{pH}^{\prime} \mathrm{s}$ measured at various sites. Average $\mathrm{pH}$ values are recorded, with the observed range and the number of measurements performed indicated in parenthesis. Measurements were performed by inserting a combination $\mathrm{pH}$ microelectrode into the gut at the indicated sites. The arrows designate the points at which the gut was severed during dissection. Abbreviations: $g c$, gastric caecae; il. ileum; $m g$, midgut; $m t$, Malpighian tubules; $r c$, rectal caecum; re, rectum

been shown that there is a significant correlation between gut alkalinity and the presence of tannins in the foliage which the caterpillars consume (Berenbaum 1980). Tannin-protein complexes are relatively stable at acidic and neutral $\mathrm{pH}$ 's, but dissociate under alkaline conditions (Van Sumere et al. 1975). At pH's above 9 , most protein-tannin complexes are extensively dissociated. Thus, the high alkalinity in the midgut of $T$, abdominalis would be expected to dissociate protein-tannin complexes, or to prevent the formation of such complexes between polyphenols and protein liberated during the maceration of ingested detrital fragments, or between polyphenols and digestive enzymes present in the insect's gut. This interpretation presumes, of course, that the insect larvae possess digestive enzymes capable of functioning under the alkaline conditions which prevail in the gut.

\section{Activity Toward Azocoll, a Proteinase Substrate}

Proteolytic activity in the alimentary tract of $T$. abdominalis is highest in the midgut, with only residual activity evident in the rectal caecum and rectum (Table 1 ). While there are minor variations in the $\mathrm{pH}$-activity profiles of different midgut extracts, activity is consistently low below pH 9, but increases sharply above that $\mathrm{pH}$ to a maximum at $\mathrm{pH} 11$ or above (Fig. 2). Dadd (1975) also noted that the maximum activity of the proteolytic enzymes in mosquito larvae occurred over a broad $\mathrm{pH}$ range between 10 and 12. It is evident that the alkaline conditions which prevail in the midgut of $T$. abdominalis are conducive to efficient protein digestion. Only in the extreme anterior and posterior segments, where the $\mathrm{pH}$ falls below 9.5, would the potential activity of the proteolytic enzymes be restricted to a level less than $25 \%$ of the maximum. Throughout most of the midgut, $\mathrm{pH}$ is maintained above 10.5 , enabling proteolytic activity to exceed $50 \%$ 
Table 1. Enzymatic activities of homogenates of gut segments from T. abdominalis toward Azocoll

\begin{tabular}{llccc} 
Gut & \multicolumn{1}{l}{$\mathrm{T}$} \\
segment & $\left({ }^{\circ} \mathrm{C}\right)$ & \multicolumn{4}{l}{ Activity (Units/milligram dry weight) } \\
\cline { 3 - 5 } & & $\mathrm{pH} 7.5$ & $\mathrm{pH} \mathrm{9.5}$ & $\mathrm{pH} \mathrm{11.5}$ \\
\hline Midgut & $37^{\circ}$ & $123 \pm 12(7)$ & $568 \pm 26(8)$ & $957 \pm 54(6)$ \\
Rectal & $37^{\circ}$ & $6.6 \pm 2.8(4)$ & $7.1 \pm 3.7(4)$ & $16.6 \pm 3.9(4)$ \\
$\quad$ caecum & & & & \\
Rectum & $37^{\circ}$ & $9.1 \pm 2.6(12)$ & $12.9 \pm 3.1(7)$ & $14.1 \pm 3.6(9)$ \\
Midgut & $25^{\circ}$ & - & - & $98 \pm 9(8)$ \\
Midgut & $15^{\circ}$ & - & - & $14 \pm 2.2(5)$ \\
Midgut & $4^{\circ}$ & - & - & $1.6 \pm 0.2(4)$ \\
\hline
\end{tabular}

a One unit of activity toward Azocoll is the amount of enzyme required to bring about a change in absorbance at $520 \mathrm{~nm}$ of 0.001 absorbance units per minute under the conditions of the assay. Each entry in the table is the mean \pm the standard error of the mean for the number of determinations indicated in the parenthesis. Each determination was on a separate extract.

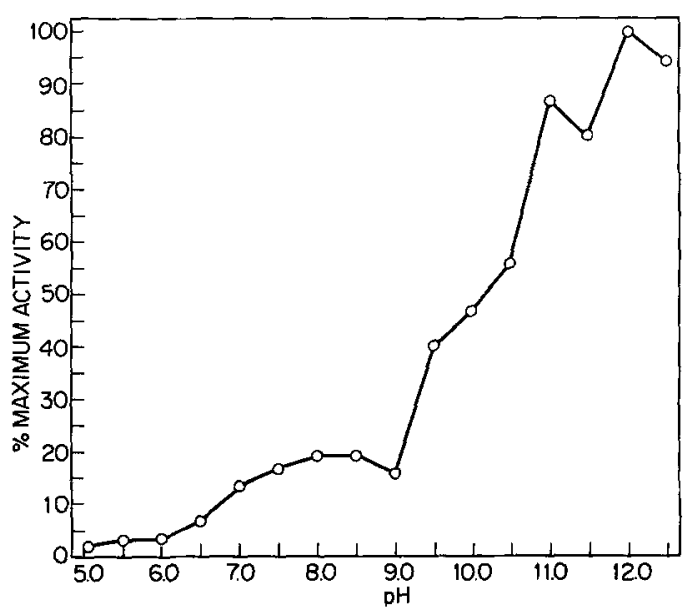

Fig. 2. Dependence of midgut proteolytic activity on $\mathrm{pH}$

of the maximum possible, while near maximal activity is likely in the highly alkaline zone near the midpoint.

The level of proteolytic activity in the midgut of this stream detritivore, assayed at $37^{\circ} \mathrm{C}$ and a $\mathrm{pH}$ of 11.5 , is extraordinarily high. The unpurified midgut material actually possesses activity within an order of magnitude of that in some commercial preparations of partially purified proteolytic enzymes. Thus, one milligram (dry weight) of midgut homogenate, assayed at $\mathrm{pH} 11.5$, possesses activity toward Azocoll equivalent to $0.18 \mathrm{mg}$ of Pronase (Calbiochem 53702), assayed at $\mathrm{pH} \mathrm{9.5.} \mathrm{The} \mathrm{midgut} \mathrm{from} \mathrm{a} \mathrm{single} \mathrm{late}$ larval instar may contain proteolytic activity equivalent to nearly $3 \mathrm{mg}$ of Pronase.

Larvae of $T$. abdominalis actively feed and grow during the fall, winter and spring months when water temperatures range from a low of $0{ }^{\circ} \mathrm{C}$ to a high of $25^{\circ} \mathrm{C}$. Clearly, midgut proteolytic activity would be lower under natural conditions than at our assay temperature of $37^{\circ} \mathrm{C}$. Midgut proteolytic activity exhibits a pronounced temperature dependence, decreasing by a factor of seven to ten for each ten-degree temperature increment (Table 1). However, even at $4{ }^{\circ} \mathrm{C}$ activity is readily detectable and is at a level which would be functionally significant to the organism in vivo.
Table 2. Enzymatic activities of homogenates of gut segments from T. abdominalis toward $\alpha$-amylose and laminarin

\begin{tabular}{|c|c|c|c|c|c|}
\hline \multirow[t]{2}{*}{$\begin{array}{l}\text { Gut } \\
\text { segment }\end{array}$} & \multirow[t]{2}{*}{$\begin{array}{l}\mathrm{T} \\
\left({ }^{\circ} \mathrm{C}\right)\end{array}$} & \multicolumn{2}{|c|}{$\begin{array}{l}\text { Activity at pH } 7.5 \\
\left(\text { Units } \times 10^{3} / \mathrm{mg}\right. \\
\text { dry wt) }\end{array}$} & \multicolumn{2}{|c|}{$\begin{array}{l}\text { Activity at } \mathrm{pH} 9.5 \\
\left(\text { Units } \times 10^{3} / \mathrm{mg}\right. \\
\text { dry wt })^{\mathrm{a}}\end{array}$} \\
\hline & & $\alpha$-Amylose & Laminarin & $\alpha$-Amylose & Laminarin \\
\hline Midgut & $37^{\circ}$ & $\begin{array}{l}18.9 \\
\pm 3.3(6)\end{array}$ & $\begin{array}{l}23.6 \\
\pm 1.1(6)\end{array}$ & $\begin{aligned} & 9.0 \\
\pm & 2.1(9)\end{aligned}$ & $\begin{array}{l}17.2 \\
\pm 2.1(9)\end{array}$ \\
\hline $\begin{array}{l}\text { Rectal } \\
\text { caecum }\end{array}$ & $37^{\circ}$ & $\begin{array}{l}13.4 \\
\pm 2.6(7)\end{array}$ & $\begin{aligned} & 5.0 \\
\pm & 1.2(7)\end{aligned}$ & - & - \\
\hline Rectum & $37^{\circ}$ & $\begin{aligned} & 7.7 \\
\pm & 2.1(8)\end{aligned}$ & $\begin{array}{c}2.4 \\
\pm 1.0(8)\end{array}$ & - & - \\
\hline Midgut & $10^{\circ}$ & - & - & $\begin{array}{c}0.32 \\
\pm 0.04(3)\end{array}$ & $\begin{array}{c}0.26 \\
\pm 0.06(3)\end{array}$ \\
\hline
\end{tabular}

a One unit of activity is the amount of enzyme required to liberate 1 micromole of maltose equivalents per minute under the conditions of assay. Each entry in the table is the mean \pm the standard error of the mean for the number of determinations indicated in the parenthesis. Each determination was on a separate extract.

A comparison of midgut proteolytic activity in $T$. abdominalis with activity in other insects further emphasizes the unusually high activity of the digestive fluids of this species toward protein. Activity in T. abdominalis is ten to a hundred times higher than the activities measured in the guts of several species of fungusfeeding beetles, assayed at $37^{\circ} \mathrm{C}$ at $\mathrm{pH}$ 's comparable to those which occur in the beetles' guts (Martin et al. 1980), and fifty times higher than the activity found in the herbivorous lepidopteran, Anisota senatoria, assayed at $37^{\circ} \mathrm{C}$ and an optimal $\mathrm{pH}$ of 10.5 (Martin et al., unpublished data).

\section{Activity Toward Polysaccharides}

We have tested the activity of gut extracts derived from T. abdominalis toward a variety of polysaccharide substrates which are representative of major classes of polysaccharides that occur naturally in vascular plants, algae and fungi. The only substrates toward which the midguts of these larvae exhibited any activity were $\alpha$-amylose and laminarin (Table 2), indicating that digestion is restricted to $\alpha-1,4-$ and $\beta$-1,3-glucans, neither of which are major components of aquatic detritus. Although starch, an $\alpha-1,4$-glucan, is an important constituent of live plant tissue, it is withdrawn from foliage during senescence, and residual soluble carbohydrates are rapidly leached out of submerged leaf litter (Kaushik and Hynes 1971; Suberkropp et al. 1976). Thus, the most concentrated source of $\alpha-1,4$ - and $\beta$-1,3-glucans in the diet of $T$. abdominalis is the fungal tissue associated with the vascular plant debris. Diatoms and other algae might appear to be a potential source of these two classes of polysaccharides, but these lower plants are not important components of the diet of $T$. abdominalis. Lack of activity at $37^{\circ} \mathrm{C}$ toward cellulose, carboxymethylcellulose, citrus pectin, larchwood xylan and locust bean gum reveals the inability of $T$. abdominalis larvae to digest the major cell wall constituents of higher plants, i. e. cellulose, hemicellulose and pectin. In order to rule out the possibility that enzymes effective in the digestion of these substances were present but thermally inactivated at $37^{\circ} \mathrm{C}$, we repeated the assays at $10^{\circ} \mathrm{C}$, and failed to detect activity even at this biologically relevant temperature. Activity toward $\alpha$-amy- 
lose and laminarin was low, but still measurable at $10^{\circ} \mathrm{C}$ (Table 2).

Thus, the larvae of this crane fly, in common with many other detritivores (Nielsen 1962, 1963, Bjarnov 1972) possess a digestive system better adapted to digest the polysaccharides of the fungal tissue associated with leaf litter than those of the vascular plant tissue which constitutes the bulk of their food. In a qualitative sense, the digestive capabilities of these organisms resemble those of fungus-feeding beetles (Martin et al. 1980). Chitin, a major fungal cell wall polysaccharide, was not degraded by $T$. abdominalis gut extracts. This substance is also resistant to digestion by all but a few groups of mycophagous beetles (Martin et al. 1980).

The digestive system of $T$. abdominalis larvae is less well adapted for the efficient digestion of polysaccharides than it is for the efficient utilization of protein. The high alkalinity mitigates against effective carbohydrate digestion. Activities toward both $\alpha$-amylose and laminarin are lower at $\mathrm{pH} 9.5$ than 7.5 (Table 2). At $\mathrm{pH} 10.0$, there is virtually no activity toward amylose and activity toward laminarin is about $25 \%$ of the maximum. At $\mathrm{pH}$ 11.5 , no activity toward either substrate could be detected. Thus, over most of the midgut, the digestive carbohydrases which are present would be able to function at only a small fraction of their potential. Nor are the levels of activity particularly high when compared to other insects. Amylose activity in the midgut is roughly comparable to that in the caterpillar, A. senatoria (Martin et al., unpublished data), and levels of activities of both amylase and laminarinase are considerably less than levels present in fungus-feeding beetles (Martin et al. 1980).

The conditions in the hindgut of $T$. abdominalis, where the $\mathrm{pH}$ is between 7.1 and 7.6 , are actually more compatible with the catalytic properties of the carbohydrases than those of the midgut, and it is not out of the question that some digestion might occur there, especially in the rectal caecum. Thus, activity toward amylose is actually higher in the rectal caecum at $\mathrm{pH}$ 7.5 than in the midgut at pH 9.5 (Table 2). Activity toward laminarin, however, is quite low in the rectal caecum. No activity toward chitin or any of the plant cell wall polysaccharides was detected at any $\mathrm{pH}$ or any temperature in either the rectal caecum or the rectum.

\section{Ecological significance}

This investigation has demonstrated that the digestive system of the larvae of the crane fly, T. abdominalis, is well adapted for the efficient digestion of protein, but rather poorly adapted for the digestion of carbohydrate. A highly efficient system for the digestion of protein would seem to be crucial in an organism which is nitrogen-limited and which must derive its nitrogen from a resource which contains low levels of this critical element. While this interpretation might seem self-evident, it nonetheless has a significant bearing upon contemporary ecological and evolutionary theories concerning the adaptive strategies by which nitrogen limited organisms exploit nutritionally low quality resources. Slansky and Feeny (1977) demonstrated that the feeding behavior and digestive biochemistry of larvae of the cabbage butterfly, Pieris rapae, have been selected to maximize the rate of nitrogen-accumulation and not the efficiency of nitrogen utilization. They noted that this result is in accord with the hypothesis of Odum and Pinkerton (1955) that rate, not efficiency, will usually be favored by natural selection. Slansky and Feeny comment, however, that $P$. rapae is an early successional, r-selected species in which rapid growth is likely to be highly advantageous, and that in a slower growing, K-selected species, efficiency might be more favored.

It is reasonable to conclude that the high alkalinity and high proteolytic activity observed in $T$. abdominalis larvae are manifestations of a highly efficient protein-digesting system. Indeed, Klug (personal communication) has established that larvae of this species can transform as much as $61 \%$ of their ingested nitrogen into larval biomass while feeding upon well-conditioned leaf litter, reflecting a nitrogen-utilization-efficiency (NUE) much higher than that observed for $P$. rapae (Slansky and Feeny 1977). The high nitrogen utilization efficiency strongly suggests that these insects are capable of extracting some of the protein bound in complexes with tannins and lignins in the leaf tissue, as well as efficiently utilizing the easily digestible protein of the associated fungal tissue. Whether a highly efficient system for protein digestion is an adaptation typical of many detritivores, or perhaps even more generally of organisms which exploit low nitrogenhigh tannin recources, will require additional investigations of the digestive system of judiciously selected species.

It is appropriate to conclude with a few speculative comments concerning possible origins of the midgut proteinases. Neither the crane fly enzymes nor the mosquito enzymes (Dadd 1975), with their extremely high $\mathrm{pH}$ optima, are typical insect digestive proteinases. Highly alkaline proteinases from other sources are known, and all are of microbial origin (Matsubara and Feder 1971), suggesting the possibility that the proteinases of this crane fly may be derived from a bacterial source. The alimentary tract of $T$. abdominalis houses an abundant population of bacteria (Meitz 1975; Klug and Kotarski, in press). While the bacterial community of the hindgut is a morphologically distinctive one which appears to be indigenous to this region of the alimentary tract, the bacteria of the midgut closely resemble those attached to the ingested detritus, and it seems quite likely that these bacteria are simply ingested along with the food and are not part of a resident, enteric population. It is intriguing to consider the possibility that the midgut proteinases might be derived from ingested bacteria, and that the acquisition of a digestive capability through the ingestion of a source of digestive enzymes might be general phenomenon (Martin and Martin 1978, 1979).

Acknowledgements. This research was supported by grants from the National Science Foundation to M.M. Martin (PCM78-22733) and R.W. Merritt (DEB78-11145). We thank Dan Lawson and Bill Wuerthele for collecting most of the insects, and the following colleagues for suggestions and comments on an early version of the manuscript: J. Breznak, K. Cummins, E. Grafius, K. Kennedy and M. Klug.

\section{References}

Anderson NH, Sedell JR (1979) Detritus processing by macroinvertebrates in stream ecosystems. Ann Rev Entomol 24:351-377

Bärlocher F, Kendrick B (1976) Hyphomycetes as intermediates of energy flow in streams. In: EBG Jones, (ed), Recent advances in aquatic mycology. Wiley and Sons, New York, p 435-446

Berenbaum M (1980) Adaptive significance of midgut $\mathrm{pH}$ in larval Lepidoptera. Am Nat 115:138-146

Bernfeld P (1955) Amylases, $\alpha$ and $\beta$. In: SP Colowick, NO Kaplan (eds), Methods of enzymology, Vol. 1. Academic Press, New York, p 149-150

Berrie AD (1976) Detritus, micro-organisms and animals in fresh water. The role of terrestrial and aquatic organisms in decomposition processes. In: JM Anderson and A Macfayden (eds), Blackwells, Oxford, p 323-338

Bjarnov N (1972) Carbohydrases in Chironomus, Gammarus and some Trichoptera larvae. Oikos $23: 261-263$ 
Cummins KW (1978) Ecology and distribution of aquatic isects. In: RW Merritt and KW Cummins (eds), An introduction to the aquatic insects of North America. Kendall-Hunt, Dubuque, p 29-31

Cummins KW, Klug MJ (1980) Feeding ecology of stream invertebrates. Ann Rev Ecol Syst 11:147-172

Cummins KW, Petersen RC, Howard FO, Wuycheck JC, Holt VI (1973) The utilization of leaf litter by stream detritivores. Ecology 54:336 345

Dadd RH (1975) Alkalinity within the midgut of mosquito larvae with alkaline-active digestive enzymes. J Insect Physiol 21:1847-1853

Iversen TM (1974) Ingestion and growth in Sericostoma personatum (Trichoptera) in relation to the nitrogen content of ingested leaves. Oikos 25:278-282

Klug MJ, Kotarski S (in press) Bacteria associated with the gut tract of larval stages of the aquatic crane fly Typula abdominalis (Diptera; Tipulidae). Appl Environ Microbiol

Kaushik NK, Hynes HBN (1971) The fate of the dead leaves that fall in to streams. Arch Hydrobiol 68:465-515

Lacey AL, Federici BA (1979) Pathogenesis and midgut histopathology of Bacillus thuringiensis in Simulium vitattum (Diptera: Simuliidae) J Invert Pathol 33:171-182

Mackay RJ, Kalff J (1973) Ecology of two related species of caddisfly larvae in the organic substrates of a woodland stream. Ecology $54: 499-511$

Martin MM, Kukor JJ, Martin JS, O'Toole TE, Johnson MW (in press) Digestive enzymes of fungus-feeding beetles. Physiol Zool

Martin MM, Martin JS (1978) Cellulose digestion in the midgut of the fungus-growing termite, Macrotermes natalensis: the role of acquired digestive enzymes. Science 199:1453-1455

Martin MM, Martin JS (1979) The distribution and origins of the cellulolytic enzymes of the higher termite, Macrotermes natalensis. Physiol Zool 52:11-21

Matsubara H, Feder J (1971) Other bacterial, mold and yeast proteases. In: PD Boyer (ed), The enzymes, 3rd edition, vol. 3. Academic Press, New York, p 721-795

MeitzAK (1975) Alimentary tract microbiota of aquatic invertebrates. MS Thesis. East Lansing Mich, Michigan State University, 64 pp.

Nielsen CO (1962) Carbobydrases in soil and litter invertebrates. Oikos $13: 200-215$
Nielsen CO (1963) Laminarinases in soil and litter invertebrates. Nature (London) 199:1001

Odum HT, Pinkerton RC (1955) Time's speed regulator: the optimum efficiency for maximum power output in physical and biological systems. Am Sci 43:331-343

Odum WE, Kirk PW, Zieman JC (1979) Non-protein nitrogen compounds associated with particles of vascular plant detritus. Oikos $32: 363-367$

Reissig JL, Strominger JL, Leloir LF (1955) A modified colorimetric method for the estimation of $\mathrm{N}$-acetylaminosugars. J Biol Chem. 217:959-966

Slansky FJr, Feeny P (1977) Stabilization of the rate of nitrogen accumulation by larvae of the cabbage butterfly on wild and cultivated food plants. Ecol Monogr 47:209-228

Suberkropp K, Godshalk GL, Klug MJ (1976) Changes in chemical composition of leaves during processing in a woodland stream. Ecology $57: 720-727$

Suberkropp K, Klug MJ (1976) Fungi and bacteria associated with leaves during processing in a woodland stream. Ecology 57:707-719

Undeen AH (1979) Simuliid larval midgut $\mathrm{pH}$ and its implications for control. Mosq News 39:391-392

Van Sumere CF, Albrecht J, Deconder A, de Pooter H, Pe I (1975) Plant protein and phenolics. In: JB Harborne and CF Van Sumere (eds), The chemistra and biochemistry of plant proteins. Academic Press, New York, p 211-264

Waterhouse DF, Hackman RH, McKellar JW (1961) An investigation of chitinase activity in cockroach and termite extracts. J Insect Physiol $6: 96-112$

Waldbauer GP (1968) The consumption and utilization of food by insects. Adv Insect Physiol 5:229-289

Willoughby LG (1974) Decomposition of litter in fresh water. In: CA Dickinson and GJF Pugh (eds), Biology of plant litter decomposition, Vol. 2. Academic Press, New York, p 659-681

Received May 16, 1980 